\title{
Toward a holistic definition for Information Systems for Health in the age of digital interdependence
}

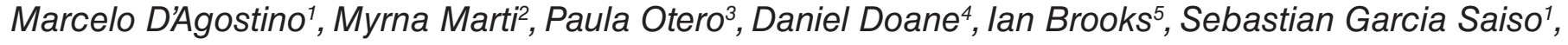 \\ Jennifer Nelson ${ }^{6}$, Luis Tejerina ${ }^{6}$, Alexandre Bagolle ${ }^{6}$, Felipe Medina Mejia', Daniel Luna ${ }^{3}$, Walter H. \\ Curioso $^{8}$, Viviane Lourenço ${ }^{9}$, Victoria Malek ${ }^{2}$, and Gerardo de Cosio ${ }^{1}$
}

Suggested citation D'Agostino M, Marti M, Otero P, Doane D, Brooks I, Garcia Saiso S, et al. Toward a holistic definition for Information Systems for Health in the age of digital interdependence. Rev Panam Salud Publica. 2021;45:e143. https://doi.org/10.26633/RPSP.2021.143

ABSTRACT The article's main objective is to propose a new definition for Information Systems for Health, which is characterized by the identification and involvement of all the parts of a complex and interconnected process for data collection and decision-making in public health in the information society. The development of the concept was through a seven-step process including document analysis, on-site and virtual sessions for experts, and an online survey of broader health professionals. This new definition seeks to provide a holistic view, process, and approach for managing interoperable applications and databases that ethically considers open and free access to structured and unstructured data from different sectors, strategic information, and information and communication technology (ICT) tools for decision-making for the benefit of public health. It also supports the monitoring of the Sustainable Development Goals and the implementation of universal access to health and universal health coverage as well as Health in All Policies as an approach to promote health-related policies across sectors. Information Systems for Health evolves from preconceptions of health information systems to an integrated and multistakeholder effort that ensures better care and better policy-making and decision-making.

Keywords Health information systems; public health; health policy; eHealth policies.

Article 14 of the Pan American Sanitary Code, ${ }^{1}$ signed in Havana, Cuba, in November 1924, stated that, "Each of the signatory Governments agrees to put in operation at the earliest practicable date a system for the collection and tabulation of

1 The Pan American Sanitary Code was signed ad referendum by 18 countries of the Americas in the assembly hall of the former Academy of Medical, Physical, and Natural Sciences (now the Dr. Carlos J. Finlay Museum of Science History) on 14 November 1924 in Havana, Cuba, during the Seventh Pan American Sanitary Conference. Source: http://iris.paho.org/xmlui/handle/123456789/5668 vital statistics." In consonance, in 1954, countries of the Americas expressed their interest in health data collection as a key action for the benefit of public health and agreed to complete a four-year report on health conditions, preferably of a statistical nature (1).

Various theories of systems and different definitions were developed in the 20th century. Ludwig Von Bertalanffy, who in 1969 published his general systems theory (GST), asserted that the notion of system is as old as European philosophy (2).

\footnotetext{
1 Pan American Health Organization, Washington, D.C., United States of America $\bowtie$ Marcelo D'Agostino, dagostim@paho.org

2 International Consultant, Argentina

3 Hospital Italiano de Buenos Aires, Buenos Aires, Argentina

4 International Consultant, Canada

University of Illinois, Champaign, Ill., United States of America
}

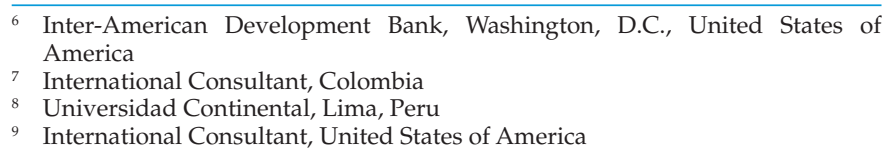

This is an open access article distributed under the terms of the Creative Commons Attribution-NonCommercial-NoDerivs 3.0 IGO License, which permits use, distribution, and reproduction in any medium, provided the original work is properly cited. No modifications or commercial use of this article are permitted. In any reproduction of this article there should not be any suggestion that PAHO or this article endorse any specific organization or products. The use of the PAHO logo is not permitted. This notice should be preserved along with the article's original URL. Open access logo and text by PLoS, under the Creative Commons Attribution-Share Alike 3.0 Unported license. 
Mario Bunge ${ }^{2}$ in 2004 defined a system as an entity composed of four basic but interrelated elements: composition, environment, structure, and mechanism (CESM) (3).

There have also been different interpretations of the complexity of health information systems, like AbouZahr and Boerma (2005) who commented that the word "system" implies a connected whole or organized process. They stated that, in practice, most countries' health information systems lack such cohesion, having developed in a piecemeal way, fashioned by administrative, economic, legal, or donor pressures, and are invariably highly complex (4).

In today's information society, open and free access to quality, trusted, and timely health-related data and information is one of the critical success factors of any effective health system. Information and communication technologies (ICTs) are critical for having faster and better information to help overcome some of the persistent obstacles of health information systems (5).

Health Metrics Network's 2011 study showed that the basic foundations for a good health information system are inadequate in many low- and middle-income countries. Results also showed that countries which face the greatest health challenges generally have the weakest systems for gathering, managing, analyzing, and using information (6). Moreover, the COVID-19 pandemic has revealed the need to strengthen health information systems, especially in these countries (7).

Another challenge to face in this era is the preconceptions of many public health professionals about health information systems as isolated initiatives mainly focused on software development, vital statistics data, and/or electronic health records, not conceiving them as an integrated and multistakeholder effort to ensure better care and better policy-making and decision-making. These preconceptions could be related to the lack of awareness of the current context established by the information society and the data revolution, and therefore cannot provide a general framework for policy development and decision-making (8).

This article's main objective is to introduce a more comprehensive new definition for Information Systems for Health, characterized by the identification and understanding of all the parts of a complex and interconnected processes for data collection and decision-making in public health in the information society. This definition focuses on establishing the needed level of interoperability so data can be processed, analyzed, and used for the benefit of a health-related system to support informed, evidence-based decision-making and policy-making.

\section{Health information in the context of digital interdependence}

The age of digital interdependence, as stated by the United Nations Secretary-General, should guide actions to manage digital technologies to maximize benefits to society and minimize harms, with a far-sighted and wide-ranging view of the complex ways in which they interact with societal, environmental, ethical, legal, and economic systems. This innovative vision presents unprecedented opportunities, including the use of structured and unstructured data and information

https://www.mcgill.ca/philosophy/people/faculty/bunge for improving public health. If used ethically, anyone, including governments and health-related and academic institutions, will benefit from this situation as never before in history (9).

Due to the uncontrolled increase in data and information on the Web, and considering the unlimited possibilities offered by ICTs, in August 2014, United Nations Secretary-General Ban Ki-moon asked an independent expert advisory group to make concrete recommendations to mobilize the data revolution as an essential component of sustainable development (10). The main recommendations are related to two global challenges: a) the challenge of invisibility (gaps in what we know from data, and when we find out); and b) the challenge of inequality (gaps between those with and without information, and what they need to know make their own decisions).

At the World Summit on the Information Society (WSIS), Geneva 2003 and Tunis 2005, countries adopted a common vision identifying the main principles and challenges toward a people-centered, inclusive, and development-oriented information society (11). In 2005, governments reaffirmed their commitment to the foundations of an information society and outlined the basis for implementation and follow-up in the Tunis Agenda for the Information Society (12). They also agreed on the creation of the Internet Governance Forum. ${ }^{3}$

On 20 September 2011, the Open Government Partnership was formally launched as a multilateral initiative that aims to secure concrete commitments from governments to promote transparency, empower citizens, fight corruption, and harness new technologies to strengthen governance (13). Since 2011, the World Health Organization (WHO) and the Pan American Health Organization (PAHO), the WHO Regional Office for the Americas, have been reinforcing the concept of Health in All Policies as an approach to promote health-related policies across sectors; therefore, it is critical to adapt the current concept of health information systems into Information Systems for Health as a mechanism that facilitates the collection and use of health-related data from different sectors and sources. This in turn will facilitate the process for monitoring the United Nations Sustainable Development Goals (SDGs), with particular emphasis on SDG 3 (Ensure healthy lives and promote well-being for all at all ages), and the $\mathrm{PAHO} / \mathrm{WHO}$ Strategy for Universal Access to Health and Universal Health Coverage.

\section{MATERIALS AND METHODS}

A review of the $\mathrm{PAHO} / \mathrm{WHO}$ official strategies and resolutions was conducted in order to identify information that outlined the organizational policy and strategy toward health information systems. The following official documents of $\mathrm{PAHO} / \mathrm{WHO}$ were taken as initial reference for group work: a) Collection and Use of Core Health Data (CD40/19), presented in 1997 by PAHO Member States on progress in the implementation of the initiative base/country profile data; b) Ten-year Evaluation of the Regional Core Data in Health Initiative (CE134/16), on accountability over 10 years of implementation of the initiative base/country data profiles; c) PAHO 48th Directing Council Resolution, Plan of Action for Strengthening

The Internet Governance Forum (IGF) is a multistakeholder forum for policy dialogue on issues of Internet governance. 
FIGURE 1. Road map for establishing the new holistic definition of Information Systems for Health

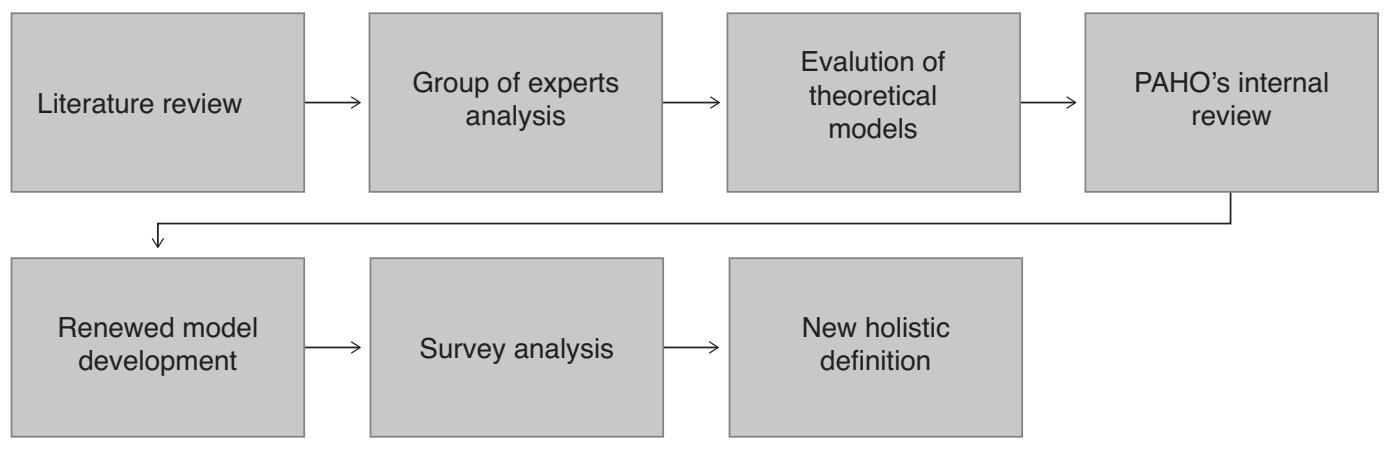

Source: Prepared by the authors.

TABLE 1. Quantitative analysis of survey responses

Definition used in the survey: "A National Information System for Health is an integrated mechanism for the convergence of interconnected and interoperable systems, data, information, knowledge, processes, standards, people, and institutions, supported by the most cost-effective information and communication technologies that interact (or help) to generate, identify, collect, process, store, and make free and publicly available, quality data and strategic information for better policy and decision making processes in Public Health Systems."

\begin{tabular}{cccccccc} 
& $\begin{array}{c}\text { Strongly } \\
\text { agree }\end{array}$ & Agree & Neutral & Disagree & $\begin{array}{c}\text { Strongly } \\
\text { disagree }\end{array}$ & $\begin{array}{c}\text { I need more } \\
\text { information }\end{array}$ & Total responses \\
Level of agreement & $\begin{array}{c}33.5 \% \\
(156)\end{array}$ & $\begin{array}{c}45.8 \% \\
(213)\end{array}$ & $\begin{array}{c}11.8 \% \\
(55)\end{array}$ & $\begin{array}{c}2.4 \% \\
(11)\end{array}$ & $\begin{array}{c}2.2 \% \\
(10)\end{array}$ & $\begin{array}{c}4.3 \% \\
(20)\end{array}$ & 465 \\
\hline
\end{tabular}

Source: Prepared by the authors from the survey results.

of Vital and Health Statistics (CE142/15); and d) the Resolution Strategy and Plan of Action on eHealth, incorporating the use of ICTs in health.

A group of 10 experts in public health, information systems, information technologies, and health data management was formed in August 2015 to reflect on the modernization of the concept of health information systems in the context of the information society. They first met in a three-day activity oriented to a) review the current situation of the concept of health information systems, b) discuss the components that a renewed health information systems concept should include, and c) define a renewed health information systems model based on the general systems theory (GST) (2) to integrate all components of the system. During the sessions, technical institutional teams from $\mathrm{PAHO} / \mathrm{WHO}$ were invited to provide input into the vision and expectations of a renewed model of health information systems. Different models and structures were evaluated, and the components, environment, structure, and mechanisms (CESM) model (3) designed was selected as being the most complete. Group work continued by electronic means such as email, videoconferencing, and online (Figure 1) until a renewed model was designed by $\mathrm{PAHO} / \mathrm{WHO}^{4}$

In total, 465 health professionals worldwide were consulted on the renewed model in the context of a broader online survey called Public Health in the Information Society. Their level of agreement was assessed, using a five-point Likert scale, with the question, "Please indicate your level of agreement with

\footnotetext{
4 https://www.paho.org/ish
}

the following definition of 'Information Systems for Health': A National Information System for Health is an integrated mechanism for the convergence of interconnected and interoperable systems, data, information, knowledge, processes, standards, people, and institutions, supported by the most cost-effective information and communication technologies that interact (or help) to generate, identify, collect, process, store, and make free and publicly available, quality data and strategic information for better policy and decision-making processes in Public Health Systems." All the answers and the 98 comments and suggestions were analyzed and incorporated to improve the model proposed. In general, $79.3 \%$ of the responders agreed (agree + strongly agree) with the definition used in the survey (Table 1).

While most people agreed with the definition used for the purpose of the survey (Table 1), some of them advised to keep it as simple as possible. There seemed to be an agreement that long and complex definitions tend to cause problems of misinterpretations instead of solving them.

\section{DISCUSSION}

Direct, clear general concepts are more useful for readers to understand and for institutions to apply. Considering the feedback provided by the survey participants and the group of experts, the definition reads as follows: Information systems for health is a holistic process and approach for managing interoperable applications and databases that ethically process structured and unstructured data from different sectors for the benefit of public health. 
FIGURE 2. Key concepts for the new holistic definition for Information Systems for Health

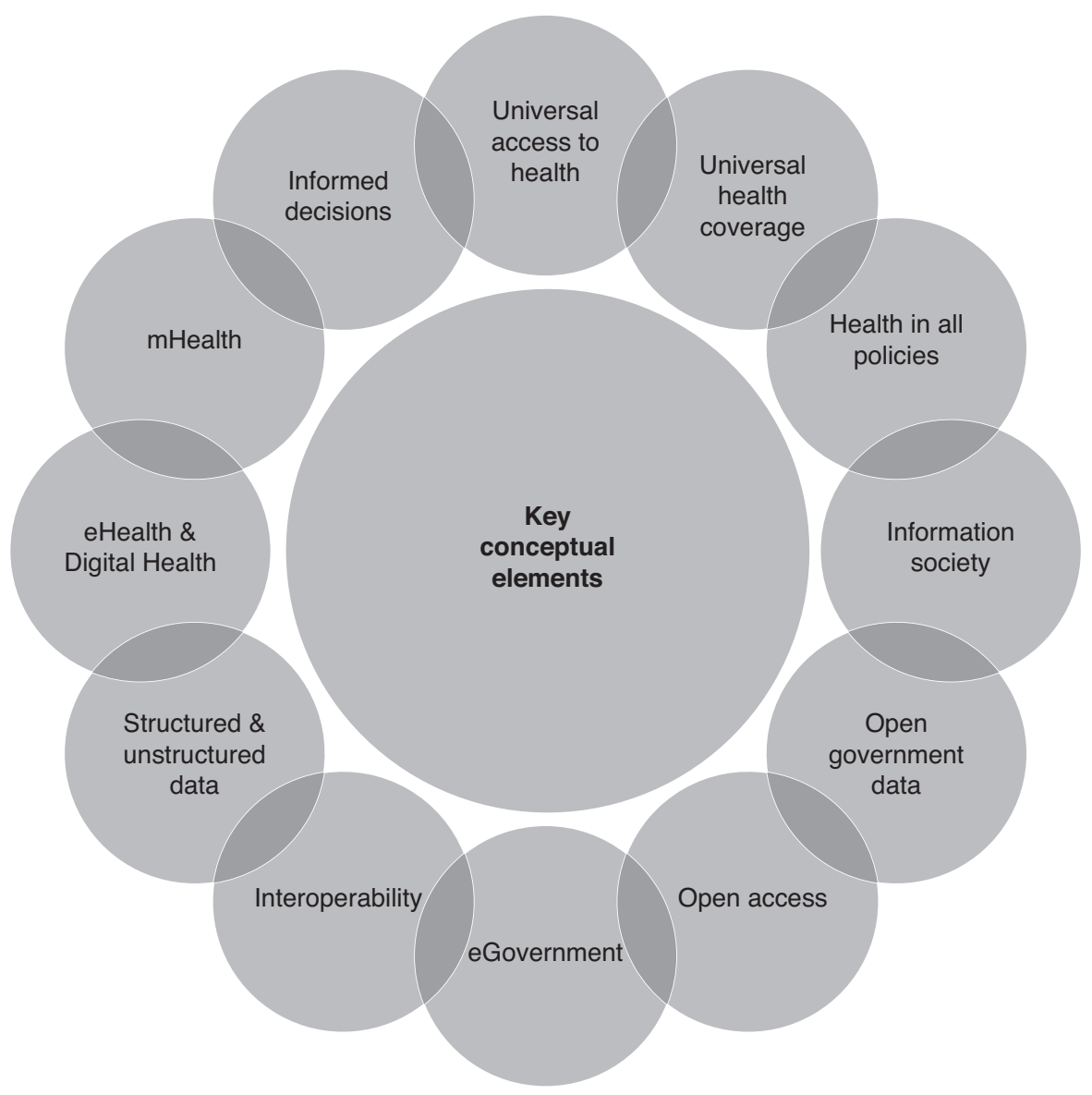

Source: Prepared by the authors.

Abraham Lincoln said, "Give me six hours to chop down a tree and I will spend the first four sharpening the axe." ${ }^{5}$ The Merriam-Webster dictionary defines definition as "a statement expressing the essential nature of something." It helps to have a common understanding and helps teams within institutions to organize collective thinking on what should be understood to achieve a successful project implementation. Therefore, having a common understanding of the definition of Information Systems for Health will contribute as the most critical factor to the development of the most appropriate project framework and its elements (14).

This new definition of Information Systems for Health seeks to provide a holistic view that considers open and free access to structured and unstructured data, strategic information, and ICT tools for decision-making and well-being. It also supports the implementation of universal access to health and universal health coverage as well as providing informed evidence to support Health in All Policies as an approach to promote health-related policies across sectors $(15,16)$.

\footnotetext{
Source: https://www.abrahamlincolnassociation.org/
}

Therefore, the new definition proposed by the authors embraces the key conceptual elements that are shown in Figure 2. In order to avoid having a circular definition or a simple theoretical one, the proposed definition for Information Systems for Health is intended to be operational and oriented to the specific purpose of strengthening a country's capacity for health analysis, monitoring of the SDGs and predictions, and for supporting actions for universal access to health and universal health coverage (17). All the concepts were analyzed individually and collectively, including their points of convergence and their relation to public health.

Author contributions. All authors conceived the original idea and wrote the paper. All authors reviewed and approved the final version.

\section{Conflict of interest. None declared.}

Disclaimer. Authors hold sole responsibility for the views expressed in the manuscript, which may not necessarily reflect the opinion or policy of the Revista Panamericana de Salud Públical Pan American Journal of Public Health and/or the Pan American Health Organization. 


\section{REFERENCES}

1. Pan American Health Organization. 7th Directing Council, 5th Session of the Regional Committee [Internet]. Technical discussions at the XIV PSC. Washington DC: PAHO; 2000 [cited 2017 Mar 27]. (Resolution CD7.R23). Available from: https://iris.paho.org/ xmlui/bitstream/handle/123456789/1867/CD7.R23en.pdf

2. Von Bertalanffy L. The history and status of general systems theory. Acad Manag J. 1972 Dec 1;15(4):407-26.

3. Bunge M. How does it work? The search for explanatory mechanisms. Philos Soc Sci. 2004 Jun;34(2):182-210.

4. AbouZahr C, Boerma T. Health information systems: the foundations of public health. Bull World Health Organ. 2005;83:578-83.

5. D'Agostino M, Mejia Medina F, Marti M, Malek Pascha V, Nelson J, Pombo C, et al. Open public health: the way not to leave anyone behind. Rev Panam Salud Publica. 2020;44:e162.

6. World Health Organization; Health Metrics Network. Country Health Information Systems: A review of the current situation and trends. Geneva: WHO; 2011.

7. Mahmood S, Hasan K, Colder Carras M, Labrique A. Global Preparedness Against COVID-19: We Must Leverage the Power of Digital Health. JMIR Public Health Surveill. 2020;6(2):e18980. https:/ / doi.org/10.2196/18980

8. Pan American Health Organization [Internet]. Washington, DC: PAHO; c2018 [cited 2018 Oct 14]. PAHO's Information Systems for Health Initiative. Available from: https:/ /www.paho.org/ish/.

9. Bouchard C. The United Nations in the Digital Age. In: Bjola C, Zaiotti R. Digital Diplomacy and International Organisations: Autonomy, Legitimacy and Contestation. London: Routledge; 2020:101.

10. United Nations Secretary-General's Independent Expert Advisory Group. A World that Counts: Mobilising the data revolution for sustainable development [Internet]. New York: Independent Expert Advisory Group Secretariat; 2014 [cited 2016 Mar 24]. Available from: https:/ /www.undatarevolution.org/report/.

11. World Summit on the Information Society. WSIS+10 Statement on the Implementation of WSIS Outcomes. In: World Summit on the Information Society.WSIS+10 High-Level Event: WSIS+10 Outcome
Documents Geneva 2014. Geneva: International Telecommunication Union; 2014. Available from: https://www.itu.int/net/wsis/ implementation/2014/forum/inc/doc/outcome/362828V2E.pdf

12. World Summit on the Information Society [Internet]. Geneva: International Telecommunication Union; 2005 [cited 2017 Mar 27] Agenda for The Information Society - Tunis 2005. Available from: https://www.itu.int/net/wsis/outcome/booklet/tunis-agenda_ C.html

13. Open Government Partnership [Internet]. Washington, DC: Open Government Partnership: c2017 [cited 2017 Mar 27]. Open Government Partnership. Available from: http://www.opengovpartnership.org/.

14. Curioso WH, Carrasco-Escobar G. Collaboration in times of COVID-19: the urgent need for open-data sharing in Latin America. BMJ Health Care Inform. 2020 Jul;27(1):e100159. https://doi. org/10.1136/bmjhci-2020-100159

15. Agbehadji IE, Awuzie BO, Ngowi AB, Millham RC. Review of Big Data Analytics, Artificial Intelligence and Nature-Inspired Computing Models towards Accurate Detection of COVID-19 Pandemic Cases and Contact Tracing. Int J Environ Res Public Health. 2020 Jul 24;17(15):5330. https://doi.org/10.3390/ijerph17155330

16. Curioso WH. Building Capacity and Training for Digital Health: Challenges and Opportunities in Latin America. J Med Internet Res. 2019;21(12):e16513. https://doi.org/10.2196/16513

17. Pan American Health Organization. Strategy for universal access to health and universal health coverage [Internet]. Washington, DC: PAHO; 2014 Oct 2 [cited 2017 Mar 27]. (Document CD53/5, Rev. 2). Available from: https://iris.paho.org/handle/10665.2/28276

Manuscript received on 20 April 2021. Revised version accepted for publication on 14 July 2021.

\section{Hacia una definición holística de los sistemas de información para la salud en la era de interdependencia digital}

RESUMEN

Palabras clave
El objetivo principal de este artículo es proponer una nueva definición de los sistemas de información para la salud, que se caracterizan por la identificación y la participación de todas las partes involucradas en un complejo proceso interconectado de recopilación de datos y toma de decisiones en el ámbito de la salud pública en la sociedad de la información. El concepto se desarrolló en un proceso de siete pasos que incluyó el análisis de documentos, sesiones presenciales y virtuales con expertos y una encuesta en línea a profesionales de la salud en general. Esta nueva definición procura ofrecer un criterio holístico, un proceso y un enfoque para la gestión de bases de datos y aplicaciones interoperables que considere desde un punto de vista ético el acceso abierto y gratuito a datos estructurados y no estructurados de diferentes sectores, información estratégica y herramientas de tecnologías de la información y de la comunicación (TIC) para la toma de decisiones en beneficio de la salud pública. También brinda apoyo al seguimiento de los Objetivos de Desarrollo Sostenible y la ejecución del acceso universal a la salud y la cobertura universal de salud, así como la salud en todas las políticas como iniciativa para promover políticas relacionadas con la salud en todos los sectores. El concepto de sistemas de información para la salud implica una evolución desde lo que se consideraba anteriormente sistemas de información de salud hacia un esfuerzo integrado por parte de varios interesados directos que garantiza una mejora en la atención, la formulación de políticas y la toma de decisiones. 


\section{Por uma definição holística de Sistemas de Informação em Saúde na era da interdependência digital}

RESUMO O principal objetivo deste artigo é propor uma nova definição para Sistemas de Informação em Saúde, que são caracterizados pela identificação e participação de todas as partes de um processo complexo e interconectado para a coleta de dados e tomada de decisão em saúde pública na sociedade da informação. 0 conceito foi desenvolvido por um processo de sete passos incluindo análise de documentos, sessões presenciais e virtuais com especialistas e uma pesquisa on-line com profissionais de saúde generalistas. A nova definição busca oferecer uma visão, um processo e uma abordagem holística para gerenciar aplicativos e bases de dados interoperáveis que consideram eticamente o acesso aberto e gratuito a dados estruturados e não estruturados de diferentes setores, informações estratégicas e ferramentas de tecnologia da informação e comunicação (TIC) para tomadas de decisão em prol da saúde pública. Também sustenta o monitoramento dos Objetivos de Desenvolvimento Sustentável e a implementação do acesso universal à saúde e da cobertura universal de saúde, assim como a Saúde em Todas as Políticas como uma abordagem para promover políticas relacionadas à saúde em vários setores. Os Sistemas de Informação em Saúde evoluíram de pré-conceitos dos sistemas de informação de saúde para um esforço integrado e com muitas partes interessadas, assegurando melhor cuidado, formulação de políticas e tomada de decisão.

Palavras-chave Sistemas de informação em saúde; saúde pública; política de saúde; políticas de eSaúde. 